\title{
CHEMICAL COMPOSITION, INSECTICIDAL, AND ANTIFUNGAL ACTIVITIES OF FRUIT ESSENTIAL OILS OF THREE COLOMBIAN Zanthoxylum SPECIES
}

\author{
Juliet A. Prieto ${ }^{*}$, Oscar J. Patiño ${ }^{1}$, Wilman A. Delgado ${ }^{1}$, Jenny P. Moreno ${ }^{1}$, and Luis E. Cuca ${ }^{1}$
}

\begin{abstract}
This study determined the chemical composition of essential oils isolated from Zanthoxylum monophyllum (Lam.) P. Wilson, Z. rhoifolium Lam., and Z. fagara (L.) Sarg. fruits by steam distillation, as well as testing antifungal and insecticidal activities of essential oils as potential pesticides. Gas chromatography-mass spectrometry (GC/MS) analysis identified 57 compounds. The main constituents in Z. rhoifolium oil were $\beta$-Myrcene (59.03\%), $\beta$-phellandrene $(21.47 \%)$, and germacrene D (9.28\%), the major constituents of Z. monophyllum oil were sabinene (25.71\%), 1,8-cineole (9.19\%), and cis-4-thujanol (9.19\%), whereas fruit oil of Z. fagara mainly contained germacrene D-4-ol (21.1\%), elemol (8.35\%), and $\alpha$-cadinol (8.22\%). Zanthoxylum fagara showed the highest activity on Colletotrichum acutatum Simmonds ( $\mathrm{EC}_{50} 153.9 \mu \mathrm{L} \mathrm{L}^{-1}$ air), and Z. monophyllum was the most active against Fusarium oxysporum Schlechtend: Fr. f. sp. lycopersici (EC $\mathrm{E}_{50} 140.1 \mu \mathrm{L} \mathrm{L}^{-1}$ air). Zanthoxylum monophyllum essential oil showed significant fumigant activity against Sitophilus oryzae (L.). This study demonstrated that Zanthoxylum essential oils exhibit important fungicidal activity on $F$. oxysporum and $C$. acutatum, which could become an alternative to synthetic fungicides to control plant fungal diseases, and Z. monophyllum oil is a potential fumigant against $S$. oryzae.
\end{abstract}

Key words: Zanthoxylum monophyllum; Z. rhoifolium; Z. fagara; Sitophilus oryzae; Fusarium oxysporum f. sp. lycopersici; Colletotrichum acutatum; fumigant, antifungal, insecticidal.

\section{INTRODUCTION}

Crop losses due to insects and plant diseases caused by fungi, bacteria, and viruses cause significant economic losses (Kotan et al., 2008; Kordali et al., 2008). Insect pests often cause extensive loss of products stored in tropical and semitropical environments (Isman, 2000). For example, Sitophilus species are serious cosmopolitan pests of stored grain (Liu and Ho, 1999). Sitophilus zeamais Motschulsky (maize weevil), S. oryzae L. (rice weevil), and $S$. granaries L. are the main representatives of this genus, which principally attack rice (Oryza sativa L.), maize (Zea mays L.), wheat (Triticum sativum Lam.), and sorghum (Sorghum bicolor (L.) Moench) among others, through direct feeding on grain kernels causing unfavorable effects on food quality, safety, and preservation (Huang et al., 1997; Tapondjou et al., 2002; Kim et al., 2003; Park et al., 2003; Arannilewa, 2007).

${ }^{1}$ Universidad Nacional de Colombia, Facultad de Ciencias, Bogotá, KR 3045 03, Colombia. AA 14490. *Corresponding author (japrietor@unal.edu.co,japrietor86@gmail.com).

Received: 7 June 2010.

Accepted: 24 September 2010.
Harvest losses due to fungal disease in world crop production may amount to $12 \%$ or more in developing countries (Horbach et al., 2010). Many pathogens including Fusarium oxysporum (vascular wilt), F. solani (fruit rot) and Colletotrichum gloeosporoides (fruit rot) cause severe pre- and post-harvest damage to agriculture (Bajpai et al., 2008). Fusarium is a plant pathogen that causes wilt diseases of several economically important plants and is also known to produce toxins thought to contribute to wilting by affecting cell membrane permeability and disrupting cell metabolism (Garcés de Granada et al., 2001; Pawar and Thaker, 2007). Colletotrichum are pathogens that cause anthracnose in a wide range of woody and herbaceous crops. Symptoms are broad-ranging and include stem rot, dieback, and seedling blight. Fruits are affected during the pre- and post-harvest period (Roca et al., 2003; Muñoz et al., 2009).

Synthetic insecticides and fumigants are widely used to control grain pests and plant diseases. However, the indiscriminate application of synthetic products has led to various problems including toxic residues in treated products, environmental pollution, and resistance against 
pesticides by microorganisms and grain insect pests (Huang et al., 1997; Isman 2006; Bakouri et al., 2008; Kotan et al., 2008; Ye et al., 2010). Therefore, because of increasing drawbacks of the continued use of conventional fumigants, an effort is needed to develop new alternative pesticides to replace those being currently used.

Essential oils are potential botanical sources of alternative compounds to fumigants being currently used because of their low toxicity for warm-blooded animals, high volatility and toxicity for stored grain pests and plant microorganisms (Lee et al., 2001; Abad et al., 2007). Zanthoxylum genus (Rutaceae) is made up of about 250 species of trees and shrubs in the world's tropical and temperate regions (Pirani, 1993). It is economically very important as a source of edible fruits, raw material for the cosmetics and perfume industries, as well as culinary applications. In Asia, Z. bungeanum Maxim. fruits are the most popular huajiao commercial product called "da hong pao" (big red robe). "Green huajiao", fruit of $Z$. schinifolium Siebold \& Zucc. (Yang, 2008), is the other widely used spice in Sichuan. Zanthoxylum species have shown significant insecticidal and antifungal activity. The bark methanol extract of Z. xanthoxyloides caused significant mortality rates in S. oryzae and Callosobruchus maculatus, two stored-product insect pests (Owusu et al., 2007). Zanthoxylum monophyllum bark methanol extract showed significant activity against seven human pathogen fungi (Gómez et al., 2007). Ethanolic extracts of $Z$. americanum leaves, fruits, stem bark, and root demonstrated a broad spectrum of antifungal and antibacterial activity against Candida albicans, Aspergillus fumigatus, Cryptococcus neoformans, and Fusarium oxysporum (Bafi-Yeboa et al., 2005).

In addition to culinary applications, many species of Zanthoxylum are used in traditional medicine especially in America, Africa, and Asia. Zanthoxylum rhoifolium Lam is popular in South America for inflammatory, microbial, cancerous, and malaria processes (Da Silva et al., 2007a; 2007b). Zanthoxylum fagara is used in Cuba for the treatment of diarrhea, chest diseases, intermittent fever, earaches, and tooth diseases (Dieguez-Hurtado et al., 2003). Zanthoxylum monophyllum is used as an analgesic to treat nasal inflammation, jaundice, and eye infections in Venezuela and as colorant (Cuca et al., 1998; Díaz and Ortega, 2006; Da Silva et al., 2007a).

Zanthoxylum species accumulate volatile oils in leaves, fruits, and inflorescences (Adesina, 2005). There are numerous reports on the chemical composition and the various biological activities of Zanthoxylum species essential oils (Choochote et al., 2007; Boehme et al., 2008; Yang, 2008). The chemical composition of essential oils of Z. rhoifolium flowers, fruits, and leaves (Gonzaga et al., 2003; Moura et al., 2006; Da Silva et al., 2007a; 2007b; Boehme et al., 2008), and biological properties of fruit and leaf essential oils, such as antibacterial and cytotoxic resultshave been previously reported (Moura et al., 2006; Da Silva et al., 2007b; Boehme et al., 2008).

The volatile chemical composition of $Z$. monophyllum and Z. fagara leaves from Costa Rica have also been reported (Setzer et al., 2005). However, there are no studies about their biological properties. The composition and biological properties of fruit essential oils of $Z$. monophyllum and Z. fagara have not yet been investigated.

We report the chemical composition, insecticidal activity against $S$. oryzae, and antifungal activity against F. oxysporum f. sp. lycopersici and C. acutatum of fruit essential oils of three Colombian plant species: $Z$. monophyllum, Z. fagara, and Z. rhoifolium.

\section{MATERIALS AND METHODS}

\section{Plant material}

The fruits of Z. monophyllum (4'11'24.3" N, 74'30'48.9" W) and Z. fagara $\left(4^{\circ} 11^{\prime} 22.0^{\prime \prime} \mathrm{N}, 74^{\circ} 30^{\prime} 58.4^{\prime \prime} \mathrm{W}\right)$ were collected in January 2008 in the town of Icononzo, Tolima, Colombia, whereas Z. rhoifolium fruits $\left(4^{\circ} 19^{\prime} 30.4\right.$ " N, $74^{\circ} 26^{\prime} 17.1^{\prime \prime}$ W) were collected in February 2008 in the town of Fusagasugá, Cundinamarca, Colombia. Plant samples were identified by the Colombian National Herbarium of the Universidad Nacional de Colombia. Voucher specimens of Z. monophyllum (Lam.) P. Wilson (COL-517520), Z. rhoifolium Lam. (COL-522896), and Z. fagara (L.) Sarg. (COL-522891) were deposited in the Colombian National Herbarium of the Universidad Nacional de Colombia, Bogotá, Colombia.

\section{Isolation of essential oils}

Samples of fresh fruits (approximately $2 \mathrm{~kg}$ ) of each Zanthoxylum species were submitted to steam distillation (ca. 4 h). Oils were dried over anhydrous sodium sulfate and stored at $0-5^{\circ} \mathrm{C}$ for further analysis.

\section{Gas chromatography-flame ionization detector analysis (GC/FID)}

Volatile compound analysis was performed with a gas chromatography system (Hewlett Packard 5890 GC) with a fused capillary column $(50 \mathrm{~m} \times 0.25 \mathrm{~mm} \times 0.25 \mu \mathrm{m}$, HP5MS, Crossbond 5\% phenyl-95\% dimethylpolysiloxane, Sigma-Aldrich, St. Louis, Missouri, USA) directly coupled to a flame ionization detector (FID). Injection conditions were the following: injector temperature at 250 ${ }^{\circ} \mathrm{C}$; oven temperature program at $45^{\circ} \mathrm{C}(2 \mathrm{~min}), 150{ }^{\circ} \mathrm{C}(5$ min) at a rate of $2{ }^{\circ} \mathrm{C} \mathrm{min}-1$, then at $150{ }^{\circ} \mathrm{C}(2 \mathrm{~min}), 280$ ${ }^{\circ} \mathrm{C}(5 \mathrm{~min})$ at a rate of $8{ }^{\circ} \mathrm{C} \mathrm{min}^{-1}$; split $30: 1$ during 1.50 min, carrier gas He: $1 \mathrm{~mL} \mathrm{~min}{ }^{-1}$, constant flow; sample volume $1 \mu \mathrm{L}$. 


\section{Gas chromatography-mass spectrometry analysis (GC/} MS)

The GC/MS analyses were performed in electronic impact (EI) mode with a Hewlett Packard-5890 GC system with a fused capillary column $(50 \mathrm{~m} \times 0.25 \mathrm{~mm} \times 0.25 \mu \mathrm{m}$, HP5MS, Crossbond 5\% phenyl-95\% dimethylpolysiloxane) directly coupled to a Hewlett Packard 5973 selective mass detector. Injection conditions were the same as described above. The mass spectrometer was operated at $70 \mathrm{eV}$.

\section{Oil component identification}

Oils were analyzed by GC-MS and GC with capillary columns (HP-5MS). Chemical constituents were identified based on the comparison of their mass spectral pattern and retention indices with those obtained from the Wiley 138.L, NBS 75K.L, and SDBS libraries, as well as those published by Adams (1995). Retention indices (RI) were calculated according to the literature (Van Den Dool and Kratz, 1963).

\section{Insect rearing}

Rice weevils were obtained from a colony maintained in the Laboratory of Entomology, Universidad Nacional de Colombia, Bogotá. Weevils were reared on maize grains. Cultures were maintained in the dark at $25 \pm 1{ }^{\circ} \mathrm{C}$ and 70 $\pm 5 \%$ relative humidity.

\section{Fungal cultures}

Fusarium oxysporum f. sp. lycopersici was obtained from the culture collection of the Universidad de Cundinamarca (Laboratory of Phytopathology). Colletotrichum acutatum was obtained from the culture collection of the Universidad Nacional de Colombia, Bogotá (Laboratory of Vegetal Natural Products, Faculty of Science). Cultures were maintained and grown on potato dextrose agar (PDA) medium and incubated at $28 \pm 1{ }^{\circ} \mathrm{C}$.

\section{Insecticidal activity assay}

To determine the fumigant toxicity of Zanthoxylum oils, paper filter disks (Whatman $\mathrm{N}^{\circ} 1,2$-cm diameter pieces) were adhered to the inside of the Petri dish covers $(90 \mathrm{x}$ $15 \mathrm{~mm}$ ) and then impregnated with oil at doses calculated to give equivalent fumigant concentrations of 242-967 $\mu \mathrm{L} \mathrm{L}^{-1}$ air (20, 40, 60, and $80 \mu \mathrm{L}$ oil). Twenty adult insects (1 to 10-d-old) were placed on each Petri dish. Phostoxin ${ }^{\circledR}$-Fugran (phosphine - $300 \mu \mathrm{g} \mathrm{L}^{-1}$ air) and Nuvan® 50 E.C. (clorvox - $100 \mu \mathrm{L} \mathrm{L}^{-1}$ air) were used as positive controls. Petri dishes were sealed with Parafilm and incubated at $25 \pm 1{ }^{\circ} \mathrm{C}$ and $70 \pm 5 \%$ RH. Each concentration and control was replicated three times. Mortality was determined after 12, 24, and $48 \mathrm{~h}$ from the start of exposure (Negahban et al., 2007; Kotan et al., 2008). Insect mortality percentage (\%M) was calculated by Abbott's correction formula (Pitasawat et al., 2007). $\mathrm{LC}_{50}$ and $\mathrm{LC}_{95}$ values, as well as the corresponding $95 \%$ confidence intervals, were estimated by probit analysis (Finney, 1971).

\section{In vitro antifungal activity}

PDA plates were prepared with glass Petri dishes (90 $\mathrm{x} 15 \mathrm{~mm}$ ) for the in vitro antifungal activity test. Agar plugs of actively growing cultures in PDA were placed on one half of the Petri dish (covered with PDA) and a sterilized paper disk was placed $2 \mathrm{~cm}$ from them. A 10 $\mu \mathrm{L}$ aliquot of each essential oil was added to the paper disks in each of the PDA plates (maximum $5 \mu \mathrm{L}$ per disk). Plates were immediately sealed with Parafilm after adding each essential oil and incubated for $3 \mathrm{~d}$ at $28^{\circ} \mathrm{C}$. The diameter of concentric fungal mycelia was measured and compared with the untreated control. Medium effective concentration $\left(\mathrm{EC}_{50}\right)$ values were determined for essential oils that caused fungal growth inhibition. Aliquots of 2, 5, 7, 10, and $15 \mu \mathrm{L}\left(23.5-176.5 \mu \mathrm{L} \mathrm{L}^{-1}\right.$ air) of each essential oil were added to paper disks in each of the PDA plates (maximum $5 \mu \mathrm{L}$ per disk). Plates were replicated three times in each treatment. (Lee et al., 2007; Kotan et al., 2008). In addition, Benlate 50WP (methyl[1-[(butylamino) carbonyl]-1H-benzimidazol-2-yl]

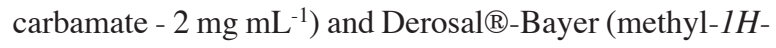
benzimidazol-2-ylcarbamate - $1 \mathrm{mg} \mathrm{mL}^{-1}$ ) were employed as chemical controls in the F. oxysporum f. sp. Lycopersici and $C$. acutatum assays, respectively.

\section{Statistical analysis}

Data are presented as mean \pm standard error. Statistical significance was determined by the Duncan and Tukey tests; ANOVA determined whether results obtained for antifungal and insecticidal activity assays were statistically different. Statistical significance was set at $P$ $<0.05$.

\section{RESULTS AND DISCUSSION}

\section{Oil chemical composition}

Fifty-seven compounds were identified by gas chromatography and mass spectrometry data in the fruit essential oils of three Zanthoxylum species (Table 1). Oils mainly contain monoterpenes and sesquiterpenes. Identified volatile components accounted for 89 to 99\% of oil composition. Monoterpenes represent more than $70 \%$ of Z. rhoifolium oil composition (80.5\%), Z. monophyllum (71.6\%), and only $6.16 \%$ of Z. fagara oil composition. Sesquiterpenes represent $88.8 \%$ of $Z$. fagara oil composition. Chemical profiles obtained for these oils showed differences in composition among the studied species (Figure 1) although volatile constituents 
Table 1. Chemical composition of Zanthoxylum species oils.

\begin{tabular}{|c|c|c|c|c|c|}
\hline \multirow[b]{2}{*}{ Peak } & \multirow[b]{2}{*}{ Constituents } & \multirow[b]{2}{*}{$\mathbf{R I}^{\mathbf{1}}$} & \multicolumn{3}{|c|}{ Area } \\
\hline & & & $\begin{array}{c}Z . \\
\text { rhoifolium }\end{array}$ & $\begin{array}{c}Z . \\
\text { monophyllum }\end{array}$ & $\begin{array}{c}Z . \\
\text { fagara }\end{array}$ \\
\hline & & & 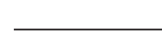 & $-\%$ & 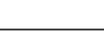 \\
\hline 1 & $\alpha$-Thujene & 929 & & 1.6 & \\
\hline 2 & $\alpha$-Pinene & 937 & & 3.1 & 2.9 \\
\hline 3 & Camphene & 950 & & & 0.1 \\
\hline 4 & Sabinene & 978 & & 25.7 & \\
\hline 5 & $\beta$-Pinene & 983 & & & 2.8 \\
\hline 6 & $\beta$-Myrcene & 990 & 59.0 & 0.8 & 0.2 \\
\hline 7 & $\alpha$-Phellandrene & 1002 & & 1.0 & \\
\hline 8 & $\alpha$-Terpinene & 1016 & & 1.4 & \\
\hline 9 & $\beta$-Phellandrene & 1034 & 21.5 & & 0.2 \\
\hline 10 & 1,8-Cineole & 1037 & & 9.2 & \\
\hline 11 & Z- $\beta$-Ocimene & 1044 & & 0.5 & 0.1 \\
\hline 12 & E- $\beta$-Ocimene & 1053 & & 0.7 & \\
\hline 13 & $\gamma$-Terpinene & 1065 & & 2.5 & \\
\hline 14 & Trans-4-thujanol & 1072 & & 6.3 & \\
\hline 15 & $\alpha$-Terpinolene & 1091 & & 0.5 & \\
\hline 16 & Cis-4-thujan & 1100 & & 9.2 & \\
\hline 17 & 2-Cyclohenen-1-ol & 1125 & & 0.6 & \\
\hline 18 & Terpinen-4-ol & 1176 & & 3.5 & \\
\hline 19 & $\alpha$-Tepineol & 1191 & & 3.5 & \\
\hline 20 & Dihydroneoisocarveol & 1229 & & 1.2 & \\
\hline 21 & Sabinene hydrate acetate (trans) & 1254 & & 0.4 & \\
\hline 22 & Geraniol & 1256 & & & 0.6 \\
\hline 23 & 2-Undecanone & 1294 & 1.7 & & \\
\hline 24 & $\delta$-Elemene & 1337 & & & 0.4 \\
\hline 25 & $\alpha$-Cubebene & 1359 & & 0.3 & 0.1 \\
\hline 26 & $\alpha$-Copaene & 1375 & & 0.5 & 0.4 \\
\hline 27 & Geranyl acetate & 1387 & & & 0.4 \\
\hline 28 & $\beta$-Elemene & 1398 & 1.6 & & 0.9 \\
\hline 29 & E-Caryophyllene & 1423 & 1.6 & 1.0 & 2.7 \\
\hline 30 & $\gamma$-Elemene & 1433 & & & 0.2 \\
\hline 31 & $\alpha$-Caryophyllene & 1453 & & 0.4 & 1.5 \\
\hline 32 & Alloaromadendrene & 1459 & & & 0.5 \\
\hline 33 & $\gamma$-Muurolene & 1472 & & & 0.4 \\
\hline 34 & Germacrene D & 1479 & 9.3 & 2.3 & 6.0 \\
\hline 35 & Bicyclogermacrene & 1488 & 3.1 & 1.5 & 5.8 \\
\hline 36 & Germacrene A & 1495 & 1.4 & & 0.4 \\
\hline 37 & $\gamma$-Cadinene & 1510 & & & 1.8 \\
\hline 38 & $\delta$-Cadinene & 1520 & & 0.9 & 4.1 \\
\hline 39 & Cadina-1.4-diene & 1529 & & & 0.4 \\
\hline 40 & $\alpha$-Cadinene & 1533 & & & 0.4 \\
\hline 41 & Elemol & 1547 & & 1.9 & 8.4 \\
\hline 42 & Germacrene B & 1552 & & 0.3 & 0.8 \\
\hline 43 & Trans-1-nerolidol & 1560 & & & 0.5 \\
\hline 44 & Germacrene D-4-ol & 1573 & & 1.2 & 21.1 \\
\hline 45 & Guaiol & 1601 & & & 0.9 \\
\hline 46 & 10- $\alpha$-Eudesm-4-en-11-ol & 1623 & & & 0.8 \\
\hline 47 & $\gamma$-Eudesmol & 1631 & & & 1.3 \\
\hline 48 & Hinesol & 1637 & & & 3.2 \\
\hline 49 & Tau-muurolol & 1640 & & 1.6 & 5.2 \\
\hline
\end{tabular}




\begin{tabular}{|c|c|c|c|c|c|}
\hline \multirow[b]{2}{*}{ Peak } & \multirow[b]{2}{*}{ Constituents } & \multirow[b]{2}{*}{$\mathbf{R I}^{\mathbf{1}}$} & \multicolumn{3}{|c|}{ Area } \\
\hline & & & $\begin{array}{c}Z . \\
\text { rhoifolium }\end{array}$ & $\begin{array}{c}\text { Z. } \\
\text { monophyllum }\end{array}$ & $\begin{array}{c}Z . \\
\text { fagara }\end{array}$ \\
\hline & & & & $-\%$ & 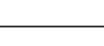 \\
\hline 50 & Torreyol & 1644 & & 0.4 & 1.0 \\
\hline 51 & $\beta$-Eudesmol & 1649 & & 0.9 & 3.6 \\
\hline 52 & $\alpha-C a d i n o l$ & 1654 & & 4.1 & 8.2 \\
\hline 53 & 5-Neo-cedranol & 1680 & & & 5.1 \\
\hline 54 & Caryophyllene acetate & 1701 & & & 0.6 \\
\hline 55 & E.E-Farnesol & 1725 & & 1.3 & \\
\hline 56 & $\alpha$-bisabolol acetate & 1794 & & & 0.2 \\
\hline \multirow[t]{4}{*}{57} & E.E-farnesyl acetate & 1850 & & & 0.3 \\
\hline & Monoterpenes & --- & 80.5 & 71.6 & 6.2 \\
\hline & Sesquiterpenes & --- & 18.7 & 18.2 & 88.8 \\
\hline & TOTAL & --- & 99.21 & 89.84 & 94.96 \\
\hline
\end{tabular}

${ }^{1}$ Calculated retention index.
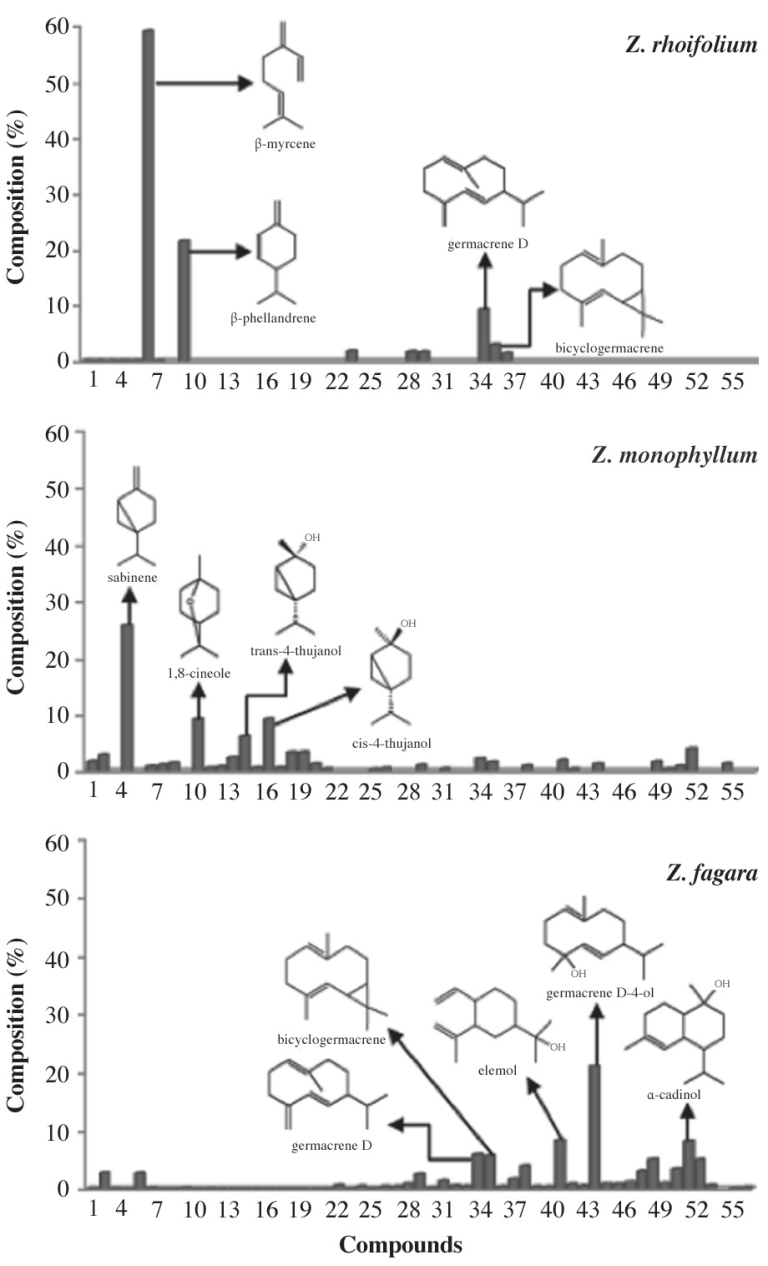

Figure 1. Chemical profile of essential oils from Zanthoxylum species fruits. For the key to identify peaks, see Table 1. have been previously reported in other species of the Zanthoxylum genus (Moura et al., 2006).

The main constituents found in $Z$. rhoifolium fruit oil were $\beta$-myrcene $(59.03 \%), \beta$-phellandrene $(21.47 \%)$, germacrene D $(9.28 \%)$, and bicyclogermacrene $(3.13 \%)$. Approximately $99.2 \%$ of $Z$. rhoifolium oil composition was characterized. The remaining unidentified components were mainly sesquiterpenes. The abundance of monoterpenoid and sesquiterpenoid compounds in fruit essential oil is in accordance with one previous report (Gonzaga et al., 2003); however, oil composition described in this study was qualitatively and quantitatively different, particularly regarding the major constituents. This suggests a considerable variability in the studied oil samples because of the influence of the ecological and chemical environment of each species, which affects the presence and abundance of secondary metabolites (Spitaler et al., 2006). The major constituents of oil derived from fruits collected in Brazil were reported as menth-2-en-1ol (46.2\%), $\beta$-myrcene (30.2\%), (-)-linalool (15\%), and terpineol $(8.45 \%)$.

The major constituents identified in Z. monophyllum fruit oil were sabinene (25.71\%), 1,8-cineole (9.19\%), trans-sabinene hydrate $(9.19 \%)$, and cis-sabinene hydrate (6.25\%). Zanthoxylum fagara fruit oil mainly contained germacrene D-4-ol (21.1\%), elemol (8.35\%), $\alpha$-cadinol $(8.22 \%)$, germacrene D (5.96\%), bicyclogermacrene (5.75\%), epi- $\alpha$-muurolol (5.15\%), and 5-neo-cedranol (5.12\%). Approximately $89.94 \%$ of Z. monophyllum and $94.2 \%$ of $Z$. fagara oil compositions were characterized. The remaining unidentified components were monoterpenes and sesquiterpenes. The detailed composition of fruit essential oils of $Z$. fagara and $Z$. monophyllum are reported for the first time in this study. 


\section{Insecticidal activity of the oils}

Results show that the essential oils of Z. fagara, Z . rhoifolium, and Z. monophyllum have different insecticidal activity against $S$. oryzae adults. Insecticidal activity rises by increasing the dose and exposure times (Figure 2). Zanthoxylum monophyllum essential oil showed the best fumigant activity against rice weevil, Z. rhoifolium oil had weak fumigant toxicity while $Z$. fagara essential oil was inactive (Figure 2).

Zanthoxylum monophyllum essential oil caused significant mortality (about 90 to $99 \%$ ) at $976 \mu \mathrm{L} \mathrm{L}^{-1}$ air
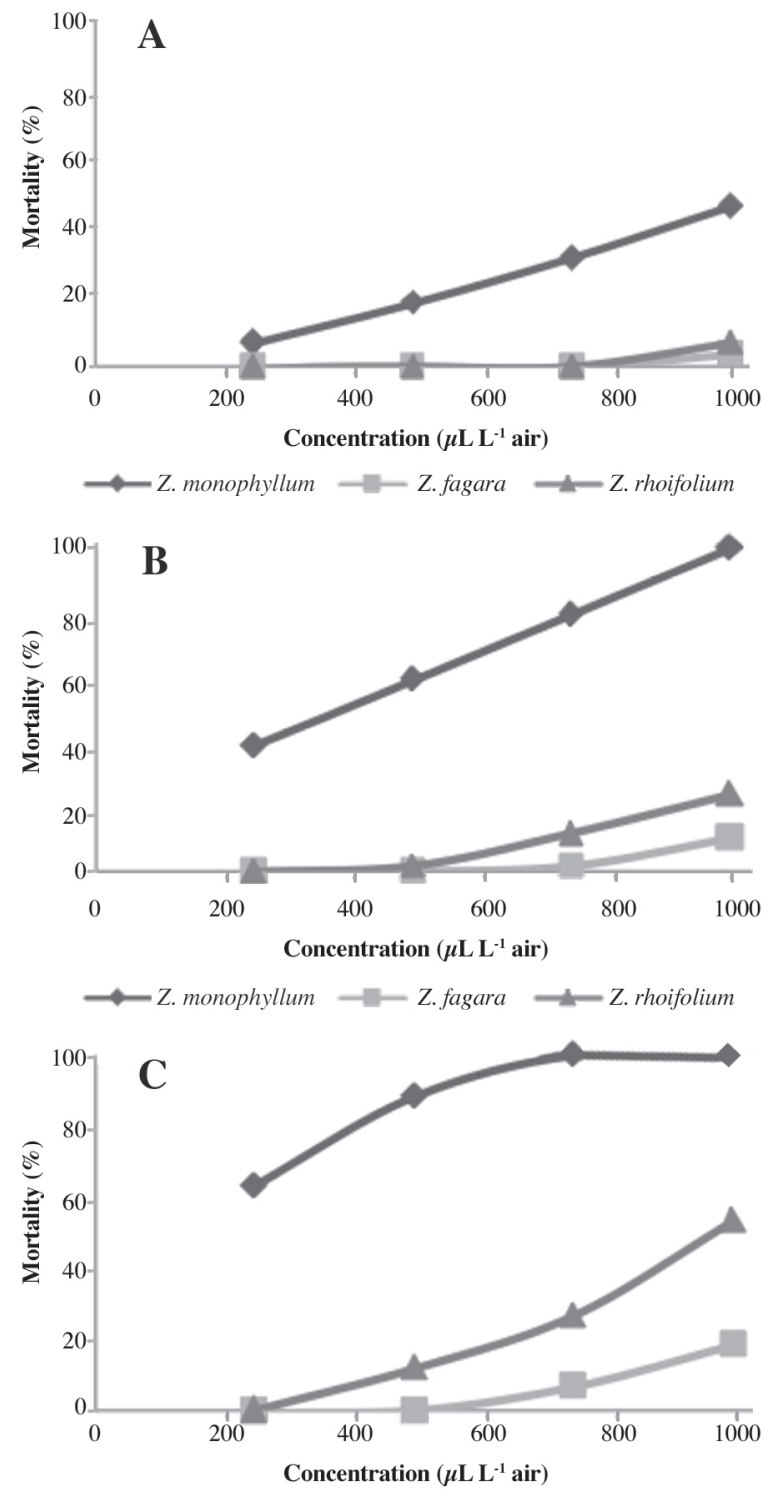

$\longrightarrow$ Z. monophyllum
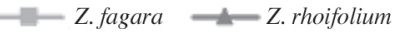

Figure 2. Percentage mortality of Sitophilus oryzae exposed to Zanthoxylum species oils for various time periods. A $12 \mathrm{~h}, \mathrm{~B} 24 \mathrm{~h}$, and $\mathrm{C} 48 \mathrm{~h}$. dose after $24 \mathrm{~h}$ exposure. After $48 \mathrm{~h}$ of treatment, a 484 $\mu \mathrm{L} \mathrm{L}^{-1}$ air dose is enough to cause $90 \%$ insect mortality. Fumigant activity of $Z$. monophyllum can be attributed to 1,8-cineole, terpinen-4-ol, and $\alpha$-terpinene present in the essential oil; these compounds have shown $100 \%$ mortality on insects of the Sitophilus genus after $12 \mathrm{~h}$ exposure (Lee et al., 2004; Kordali et al., 2006).

The commercial fumigants Phosphamin $\left(100 \mu \mathrm{g} \mathrm{L}^{-1}\right.$ air) and Nuvan $50\left(50 \mu \mathrm{L} \mathrm{L}^{-1}\right.$ air) showed $100 \%$ mortality before $12 \mathrm{~h}$ exposure. Zanthoxylum monophyllum essential oil was less active than commercial products. Higher concentrations of essential oil or longer exposure times are necessary to obtain effects similar to those of commercial fumigants (Table 2).

Terpinen-4-ol, 1,8-cineole, and $\alpha$-terpinene are absent in Z. rhoifolium and Z. fagara essential oils. Nevertheless, $Z$. rhoifolium shows insecticidal activity, which suggests that this activity can be due to the main oil components ( $\beta$-myrcene and $\beta$-phellandrene) or to a possible synergistic effect of the compounds in the essential oil.

\section{Oil antifungal activity}

Essential oils were also evaluated as fumigants against two phytopathogenic fungi, $F$. oxysporum $\mathrm{f}$. sp lycopersici and $C$. acutatum, which resulted in significant antifungal activity against both. For doses greater than $7 \mu \mathrm{L}$ per Petri dish, antifungal activity of essential oils was found to be similar to or greater than the positive controls: benomyl $(37.4 \pm 0.10 \%$ inhibition growth) for the $F$. oxysporum f. sp lycopersici assay and carbendazym $(29.9 \pm 0.13 \%$ inhibition growth) for the C. acutatum assay (Figure 3 ).

Zanthoxylum fagara showed the highest antifungal activity on $C$. acutatum ( $\mathrm{EC}_{50} 153.9 \mu \mathrm{L} \mathrm{L}^{-1}$ air) and $Z$. monophyllum was the most active against $F$. oxysporum f. sp lycopersici (EC50 $140.1 \mu \mathrm{L} \mathrm{L}^{-1}$ air) (Table 3). Minor components of $Z$. fagara were (E)-caryophyllene, T-muurolol, and $\alpha$-cadinol (in a concentration of 2.7, 5.2, and $8.1 \%$ respectively) and Z. monophyllum (in a concentration of $1.0,1.6$, and $4.1 \%$ respectively) have shown antifungal activity against various phytopathogenic fungi including the Fusarium and Colletotrichum species when they were assayed as pure compounds. These results suggest that $Z$. fagara and $Z$. monophyllum activity can be attributed to the presence of these compounds (Chang et al., 2008).

Zanthoxylum rhoifolium essential oil has $\beta$-myrcene as its main component (59.0\%), which is a compound that has shown antifungal activity in previous studies (Chang et al., 2008). This result suggests that moderate activity of the oil may be due to the presence of $\beta$-myrcene or the mixture of this compound with other metabolites that are toxic to the insect and present in the oil. 

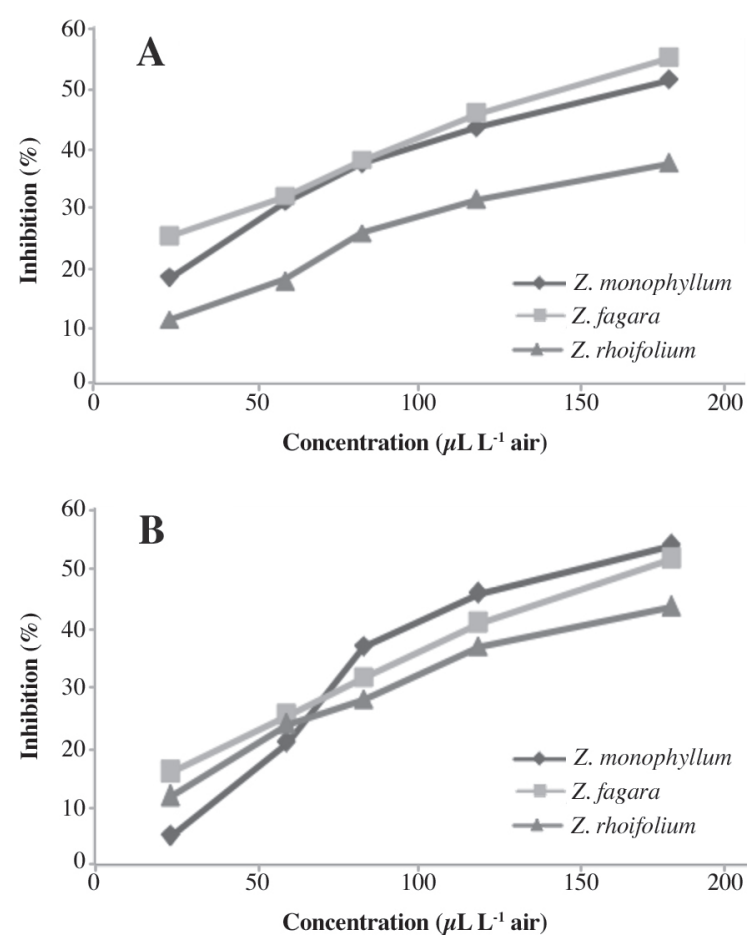

Figure 3. Concentration-dependent effects of Zanthoxylum species essential oils on mycelial growth of phytopathogenic fungi. A Colletotrichum acutatum, B Fusarium oxysporum f. sp. lycopersici.

\section{CONCLUSIONS}

We hoped to find new natural products for biocontrol of two important phytopathogenic fungi and stored-grain insect pest. The development of natural pesticides would also help to decrease the negative impact of synthetic agents, such as residues, resistance, and environmental pollution. In conclusion, fruit essential oils of Z. monophyllum, Z. fagara, and Z. rhoifolium could be recommended as fumigants against $F$. oxysporum and $C$. acutatum and as alternatives to synthetic fungicides in agriculture. Fruit essential oil of $Z$. monophyllum also showed an important insecticidal activity against $S$. oryzae and could be proposed as an important alternative insecticide to control this pest. It is important to note that Z. fagara essential oil was inactive against $S$. oryzae, but presented significant antifungal activity against two phytopathogenic fungi, a result that shows the selectivity of this essential oil against the phytopathogenic fungi species and the pest insect used in the bioassays. However, further studies are required to determine the cost, applicability, and safety of these oils as potential pesticides; it should be determined which of the secondary metabolites present in essential oils are responsible for antifungal and/or insecticidal activities, and then to establish if these substances are produced by plants regardless of their ecological environment.

Table 2. Fumigant toxicity of Zanthoxylum monophyllum and Z. rhoifolium essential oils against Sitophilus oryzae.

\begin{tabular}{|c|c|c|c|}
\hline \multirow[b]{2}{*}{ Plant species } & \multirow{2}{*}{$\begin{array}{c}\text { Exposure time } \\
\text { h } \\
\end{array}$} & $\mathrm{LC}_{50}\left(95 \% \mathrm{FL}^{\mathrm{a}}\right)$ & $\mathrm{LC}_{95}\left(95 \% \mathrm{FL}^{1}\right)$ \\
\hline & & \multicolumn{2}{|c|}{$\mu \mathrm{L} \mathrm{L}^{-1}$ air } \\
\hline \multirow{3}{*}{ Zanthoxyllum rohifolium } & 12 & $>967$ & -- \\
\hline & 24 & $>967$ & -- \\
\hline & 48 & 944.3 & \\
\hline \multirow{6}{*}{ Zanthoxyllum monophyllum } & & $(843.6-1027.7)$ & -- \\
\hline & 12 & $>967$ & -- \\
\hline & 24 & 337.2 & 1122.2 \\
\hline & & $(295.6-367.8)$ & $(1088.2-1226.5)$ \\
\hline & 48 & 222.0 & 544.5 \\
\hline & & $(173.5-259.9)$ & (491.6-640.2) \\
\hline
\end{tabular}

${ }^{1}$ Fiducial limits.

Table 3. Fumigant toxicity of Zanthoxylum species oils against Colletotrichum sp. and Fusarium oxysporum.

\begin{tabular}{lcc}
\hline & \multicolumn{2}{c}{$\mathbf{E C}_{\mathbf{5 0}}\left(\boldsymbol{\mu} \mathbf{L} \mathbf{L}^{-1}\right.$ air $)$} \\
\cline { 2 - 3 } Plant species & Fusarium oxysporum f. sp. lycopersici & Colletotrichum acutatum \\
\hline Zanthoxyllum fagara & 182.6 & 153.9 \\
Zanthoxyllum rohifolium & 244.9 & 362.3 \\
Zanthoxyllum monophyllum & 140.1 & 172.8 \\
\hline
\end{tabular}




\section{ACKNOWLEDGEMENTS}

The authors are grateful to Colciencias and to the Universidad Nacional de Colombia for financial support. We also thank the Chromatography Laboratory at the Universidad Industrial de Santander for recording GC and GC/MS data and to the Colombian National Herbarium of the Universidad Nacional de Colombia for plant identification.

\section{RESUMEN}

Composición química, actividades insecticida y antifúngica de aceites esenciales de frutos de tres especies Zanthoxylum de Colombia. En este estudio se determinó la composición química de los aceites esenciales de frutos de Zanthoxylum monophyllum (Lam.) P. Wilson, Z. rhoifolium Lam. y Z. fagara (L.) Sarg. obtenidos mediante destilación por arrastre con vapor y se evaluó la actividad antifúngica e insecticida de los aceites esenciales para estimar su uso como posibles plaguicidas. El análisis por cromatografía de gases-espectrometría de masas (CG/EM) permitió la identificación de 57 compuestos. $\beta$-Mirceno $(59,03 \%)$, $\beta$-felandreno $(21,47 \%)$ y germacreno $D(9,28 \%)$ fueron los componentes principales del aceite de Z. rhoifolium; los principales componentes del aceite de Z. monophyllum fueron sabineno $(25,71 \%), 1,8$-cineol $(9,19 \%)$ y cis-4thujanol $(9,19 \%)$, mientras que el aceite de frutos de $Z$. fagara está compuesto principalmente por germacreno D-4-ol $(21,1 \%)$, elemol $(8,35 \%)$ y $\alpha$-cadinol $(8,22 \%)$. Zanthoxylum fagara presentó la mayor actividad sobre Colletotrichum acutatum Simmonds ( EC $_{50} \quad 153,9 \mu \mathrm{L}$ $\mathrm{L}^{-1}$ de aire) y $Z$. monophyllum fue el más activo contra Fusarium oxysporum Schlechtend: Fr. f. sp. lycopersici (EC ${ }_{50} 140,1 \mu \mathrm{L} \mathrm{L}^{-1}$ de aire). El aceite esencial de $Z$. monophyllum mostró actividad insecticida significativa contra Sitophilus oryzae (L.) Este estudio demuestra que los aceites esenciales de Zanthoxylum poseen importante actividad antifúngica sobre $F$. oxysporum y $C$. acutatum y podría convertirse en una alternativa frente a los fungicidas sintéticos empleados comúnmente para el control de enfermedades de las plantas, así como el aceite de frutos de Z. monophyllum tiene un potencial para ser utilizado como fumigante contra $S$. oryzae.

Palabras clave: Z. monophyllum; Z. rhoifolium; Z. fagara; Sitophilus oryzae; Fusarium oxysporum f. sp. lycopersici; Colletotrichum acutatum; fumigante, antifúngicos, insecticida.

\section{LITERATURE CITED}

Abad, M.J., M. Ansuategui, and P. Bermejo. 2007. Active antifungal substances from natural sources. ARKIVOC 7:116-145.

Adams, R. P., 1995. Identification of essential oil components by gas chromatography/quadrupole mass spectrometry. Academic Press. San Diego, California, USA.

Adesina, S.K. 2005. The Nigerian Zanthoxylum: chemical and biological values. African Journal of Traditional Complementary and Alternative Medicines 2:282301.

Arannilewa, S.T. 2007. A simple laboratory prescreen for plants with grain protectant effects against the maize weevil; Sitophilus zeamais (Most) (Coleoptera: Curculionidae). Agricultural Journal 6:736-739.

Bafi-Yeboa, N.F.A., J.T. Arnason, J. Baker, and M.N. Smith. 2005. Antifungal constituents of Northern prickly ash, Zanthoxylum americanum Mill. Phytomedicine 12:370-377.

Bajpai, V.K., S. Shukla, and S.C. Kang. 2008. Chemical composition and antifungal activity of essential oil and various extract of Silene armeria L. Bioresource Technology 99:8903-8908.

Bakouri, H.E., J. Morillo, J. Usero, and A. Ouassini. 2008. Potential use of organic waste substances as an ecological technique to reduce pesticide ground water contamination. Journal of Hydrology 353:335-342.

Boehme, A.K., J.A. Noletto, W.A. Haber, and W.N. Setzer. 2008. Bioactivity and chemical composition of the leaf essential oils of Zanthoxylum rhoifolium and Zanthoxylum setulosum from Monteverde. Costa Rica. Natural Product Research 22:31-36.

Chang, H.T., Y.G. Cheng, C.L. Wu, S.T. Chang, T.T. Chang, and Y. Su. 2008. Antifungal activity of essential oil and its constituents from Calocedrus macrolepis var. formosana Florin leaf against plant phytopathogenic fungi. Bioresource Technology 99:6266-6270.

Choochote, W., U. Chaithong, K. Kamsuk, P. Jitpakdi, P. Tippawangkosol, B. Tuetun, et al. 2007. Repellent activity of selected essential oils againts Aedes aegypti. Fitoterapia 78:359-364.

Cuca, L.E., J.C. Martínez, and F.D. Monache, 1998. Constituyentes químicos de Zanthoxylum monophyllum. Revista Colombiana de Química 27:17-27.

Da Silva, S.L., P.M.S. Figueiredo, and Y. Tomomasa. 2007a. Chemotherapeutic potential of the volatiles oils from Zanthoxylum rhoifolium Lam leaves. European Journal of Pharmacology 576:180-188. 
Da Silva, S.L., P.M.S. Figueiredo, and Y. Tomomasa. 2007b. Cytotoxic evaluation of essential oil from Zanthoxylum rhoifolium Lam leaves. Acta Amazonica 37:281-286.

Díaz, W., and F. Ortega. 2006. Inventario de recursos botánicos útiles y potenciales de la cuenca del río Morón, estado Carabobo, Venezuela. Ernstia 16:3167.

Dieguez-Hurtado, R., G. Garrido-Garrido, S. PrietoGonzález, Y. Iznaga, L. González, J. Molina-Torres, et al., 2003. Antifungal activity of some Cuban Zanthoxylum species. Fitoterapia 74:384-386.

Finney, D.J. 1971. Probit analysis. Cambridge University Press, Cambridge, UK.

Garcés de Granada, E., M. Orozco de Amezquita, G.R. Bautista, and H. Valencia. 2001. Fusarium oxysporum el hongo que nos falta conocer. Acta Biológica Colombiana 6:7-25.

Gómez, Y., K. Gil, E. González, and L.M. Farías. 2007. Actividad antifúngica de extractos orgánicos del árbol Fagara monophylla (Rutaceae) en Venezuela. Revista de Biología Tropical 55:767-775.

Gonzaga, W.A., A.D. Weber, S.R. Giacomelli, E. Simionatto, I.I. Dalcol, E.C. Machado, and A.F. Morel. 2003. Composition and antibacterial activity of the essential oils from Zanthoxylum rhoiflium. Planta Medica 69:773-775.

Horbach, R., A.R. Navarro-Quesada, W. Knogge, and H.B. Deising. 2010. When and how to kill a plant cell: Infection strategies of plant pathogenic fungi. Journal of Plant Physiology 168:51-62.

Huang, Y., J.M.W.L. Tan, R.M. Kini, and S.H. Ho. 1997. Toxic and antifeedant action of nutmeg oil against Tribolium castaneum (Herbst) and Sitophilus zeamais Motsch. Journal of Stored Products Research 33:289298.

Isman, M.B. 2000. Plant essential oils for pest and disease management. Crop Protection 19:603-608.

Isman, M.B. 2006. Botanical insecticides, deterrents, and repellents in modern agriculture and an increasingly regulated world. Annual Review of Entomology 51:45-66.

Kim, S., J.Y. Roh, D.H. Kim, H.S. Lee, and Y.J. Ahn. 2003. Insecticidal activities of aromatic plant extracts and essential oils against Sitophilus oryzae and Callosobruchus chinensis. Journal of Stored Products Research 39:293-303.

Kordali, S., I. Aslan, O. Çalmaşur, and A. Cakir. 2006. Toxicity of essential oils isolated from three Artemisia species and some of their major components to granary weevil, Sitophilus granarius (L.) (Coleoptera: Curculionidae). Industrial Crops and Products 23:162170.
Kordali, S., A. Cakir, H. Ozer, R. Cakmakci, M. Kesdek, and E. Mete. 2008. Antifungal, phytotoxic and insecticidal properties of essential oil isolated from Turkish Origanum acutidens and its three components, carvacol, thymol and p-cymene. Bioresource Technology 99:8788-8795.

Kotan, R., S. Kordali, A. Cakir, M. Kesdek, Y. Kaya, and H. Kilic. 2008. Antimicrobial and insecticidal activities of essential oil isolated from Turkish Salvia hydrangea DC. Ex. Benth. Biochemical Systematics and Ecology 36:360-368.

Lee, B.H., P.C. Annis, F. Tumaalii, and W.S. Choi. 2004. Fumigant toxicity of essential oils from the Myrtaceae family and 1,8-cineole against 3 major stored-grain insects. Journal of Stored Products Research 40:553564.

Lee, S.O., G.J. Choi, K.S. Jang, H.K. Lim, K.Y. Cho, and J.C. Kim. 2007. Antifungal activity of five plant essential oils as fumigant against postharvest and soilborne plant pathogenic fungi. Plant Pathology Journal 23:97-102.

Lee, B.H., W.S. Choi, S.E. Lee, and B.S Park. 2001. Fumigant toxicity of essential oils and their constituents compounds towards the rice weevil, Sitophilus oryzae (L.) Crop Protection 20:317-320.

Liu, Z.L., and S.H. Ho. 1999. Bioactivity of the essential oil extracted from Evodia rutaecarpa Hook f. et Thomas against the grain storage insects, Sitophilus zeamais Motsch. and Tribolium castaneum (Herbst). Journal of Stored Products Research 35:317-328.

Moura, N.F., J. Strapazzon, F. Loro, A.F. Morel, and A. Flach. 2006. Composition of the leaf oils of Rutaceae: Zanthoxylum hyemale A. St. Hill. Z. rhoifolium Lam. and Z. rugosum A. St Hill et. Tul. Journal of Essential Oil Research 18:4-5.

Muñoz, Z., A. Moret, and S. Garcés. 2009. Assessment of chitosan for inhibition of Colletotrichum sp. on tomatoes and grapes. Crop Protection 26:36-40.

Negahban, M., S. Moharramipour, and F. Sefidkon. 2007. Fumigant toxicity of essential oil from Artemisia sieberi Besser against three stored-products insects. Journal of Stored Products Research 43:123-128.

Owusu, E.O., W.K. Osafo, and E.R. Nutsukpui. 2007. Bioactivities of Candlewood, Zanthoxylum xanthoxyloides (Lam.) solvent extracts against two stored-product insect pests. African Journal of Science and Technology 8:17-21.

Park, I.K., S.G. Lee, D.H. Choi, J.D. Park, and Y.J. Ahn. 2003. Insecticidal activities of constituents identified in the essential oil from leaves of Chamaecyparis obtusa against Callosobruchus chinensis (L.) and Sitophilus oryzae (L.) Journal of Stored Products Research 39:375-384. 
Pawar, V.C., and V.S. Thaker. 2007. Evaluation of the anti-Fusarium oxysporum f. sp cicer and antiAlternaria porri effects of some essential oils. Journal of Microbiology and Biotechnology 23:1099-1106.

Pirani, J.R.A. 1993. New species and new combination in Zanthoxylum (Rutaceae) from Brazil. Brittonia 45:154-158.

Pitasawat, B., D. Champakaew, W. Choochote, A. Jitpakdi, U. Chaithon, and D. Kanjanapothi, et al. 2007. Aromatic plant-derived essential oil: An alternative larvicide for mosquito control. Fitoterapia 78:205-210.

Roca, M.G., L.C. Davide, M.C. Mendes-Costa, A. Wheals. 2003. Conidial anastomosis tubes in Colletotrichum. Fungal Genetics and Biology 40:138-145.

Setzer, W.N., J.A. Noletto, R.O. Lawton, and W.A. Haber. 2005. Leaf essential oil composition of five Zanthoxylum species from Monteverde Costa Rica. Molecular Diversity 9:3-13.

Spitaler, R., P.D. Schlorhaufer, E.P. Ellmerer, I. Merfort, S. Bortenschlager, H. Stuppner, and C. Zidorn. 2006. Altitudinal variation of secondary metabolite profiles in flowering heads of Arnica montana cv. ARBO. Phytochemistry 67:409-417.
Tapondjou, L.A., C. Adler, H. Bouda, and D.A. Fontem. 2002. Efficacy of powder and essential oil from Chenopodium ambrosioides leaves as post-harvest grain protectants against six-stored product beetles. Journal of Stored Products Research 38:395-402.

Van den Dool, H., and P.D. Kratz. 1963. A generalization of the retention index System including linear temperature programmed gas-liquid partition chromatography. Journal of Chromatography A 11:463-471.

Yang, X. 2008. Aroma constituents and alkylamides of red and green Huajiao (Zanthoxylum bungeanum and Zanthoxylum schinifolium). Journal of Agricultural and Food Chemistry 56:1689-1696.

Ye, J., M. Zhao, J. Liu, and W. Liu. 2010. Enantioselectivity in environmental risk assessment of modern chiral pesticides. Environmental Pollution 158:2371-2383. 